\title{
Geomorphic evidence of recent activity along the Vodice thrust fault in the Ljubljana Basin (Slovenia) - a preliminary study
}

\author{
Petra Jamšek Rupnik ${ }^{1,}$, Lucilla Benedetti $^{2}$, Frank Preusser ${ }^{3}$, Miloš Bavec $^{1}$, Marko Vrabec $^{4}$ \\ ${ }^{1}$ Geological Survey of Slovenia, Ljubljana, Slovenia \\ ${ }^{2}$ Aix Marseille Université, Centre Européen de Recherche et d'Enseignement des Géosciences de l'Environnement, \\ Aix-en-Provence, France \\ ${ }^{3}$ Stockholm University, Department of Physical Geography and Quaternary Geology, Stockholm, Sweden \\ ${ }^{4}$ University of Ljubljana, Faculty of Natural Sciences and Engineering, Department of Geology, Ljubljana, Slovenia
}

\section{Article history}

Received October 30, 2012; accepted April 15, 2013.

Subject classification:

Geomorphology, Active tectonics, Earthquake geology, Seismic hazard, Ljubljana Basin, Vodice fault.

\begin{abstract}
We investigated two prominent, $\sim$ E-W trending scarps in Quaternary sediments, located close to the town of Vodice in the Ljubljana Basin (central Slovenia). By using detailed geomorphological analysis of the scarps, field surveying, and structural observations of deformed Quaternary sediments, we conclude that the scarps are the surface expression of a N-dipping thrust fault that has been active during the Quaternary. From Optically Stimulated Luminescence and Infrared Stimulated Luminescence dating of deformed Quaternary sediments we estimate a slip rate of 0.1 to $0.3 \mathrm{~mm} \mathrm{a}^{-1}$ in the last $133 \mathrm{ka}$. Using the published empirical fault-scaling relationships, we estimate that an earthquake of magnitude 5.9 to 6.5 may be expected on the Vodice thrust fault. The fault may, therefore, present a major seismic hazard for the densely populated and urbanised region of central Slovenia.
\end{abstract}

\section{Introduction}

The Ljubljana Basin (Figure 1) is the most densely populated and a highly urbanized region of Slovenia. Among the natural hazards affecting the basin and its surroundings, such as flooding, landsliding and earthquakes [e.g. Komac and Ribičič 2006, Jemec and Komac 2011, Komac and Zorn 2011, Bavec et al. 2012], seismic hazard is probably the least investigated, despite the ongoing seismic activity in the area with earthquake magnitudes frequently reaching 3-4 (based on the earthquake catalogue of Živčič [2009] there were on the average 2.6 earthquakes of magnitude 3-4 per year over the last 100 years). The seismic hazard is further increased by the unconsolidated Quaternary sedimentary infill of the basin, reaching up to $280 \mathrm{~m}$ of thickness, which may significantly enhance site effects during earthquakes [Gosar et al. 2010]. The largest recorded event in the basin is the destructive 1895 Ljubljana earth- quake with macroseismic magnitude $\left(\mathrm{M}_{\mathrm{m}}\right) 6.1$ [Ribarič 1982] and maximum intensities of VIII-IX EMS-98 [Cecić 1998]. Despite the recognized hazard, the active faults capable of producing strong magnitude earthquakes are still poorly investigated. For example, the fault responsible for the 1895 earthquake is still unknown.

The Ljubljana Basin is interpreted to have originated as a pull-apart basin in a releasing overstep between two NW-SE-striking dextral faults, the Sava fault to the north and the Žužemberk fault to the south [e.g. Vrabec and Fodor 2006]. GPS measurements suggest that the Sava fault is currently active with the slip rate of $\sim_{1} \mathrm{~mm} \mathrm{a}^{-1}$ [Vrabec et al. 2006]. Smaller ${ }^{\sim}$ E-W oriented reverse faults that displace Quaternary sediments in the basin [Verbič 2006] may indicate a recent change in the deformational regime from transtensional subsidence to transpression. Geological observations, earthquake focal mechanisms, and geodetic measurements suggest that the NW-SE-striking dextral faults and $\sim$ E-W-striking reverse faults may be active in the current regional stress regime with $\sim \mathrm{N}$-S oriented axis of maximum horizontal compression [Poljak et al. 2000, 2010, Vrabec and Fodor 2006, Verbič 2006, Weber et al. 2010].

One such presumably Quaternary active reverse fault is the Vodice fault, located $15 \mathrm{~km}$ north of Ljubljana. Two prominent fault scarps are clearly visible and were previously interpreted as terrace risers of the Sava River [Žlebnik 1971], later as possible normal fault scarps [Vrabec 2001], and more recently as reverse fault scarps [Verbič 2006]. The aim of this study was to investigate whether the Vodice fault could be currently active and to estimate its possible seismogenic potential. 


\subsection{Seismotectonic setting}

The studied area is located in the northeasternmost tip of the Adria-Europe convergent margin, in the contact between the eastern Southern Alps and the Dinarides. Axis of maximum compression is oriented in

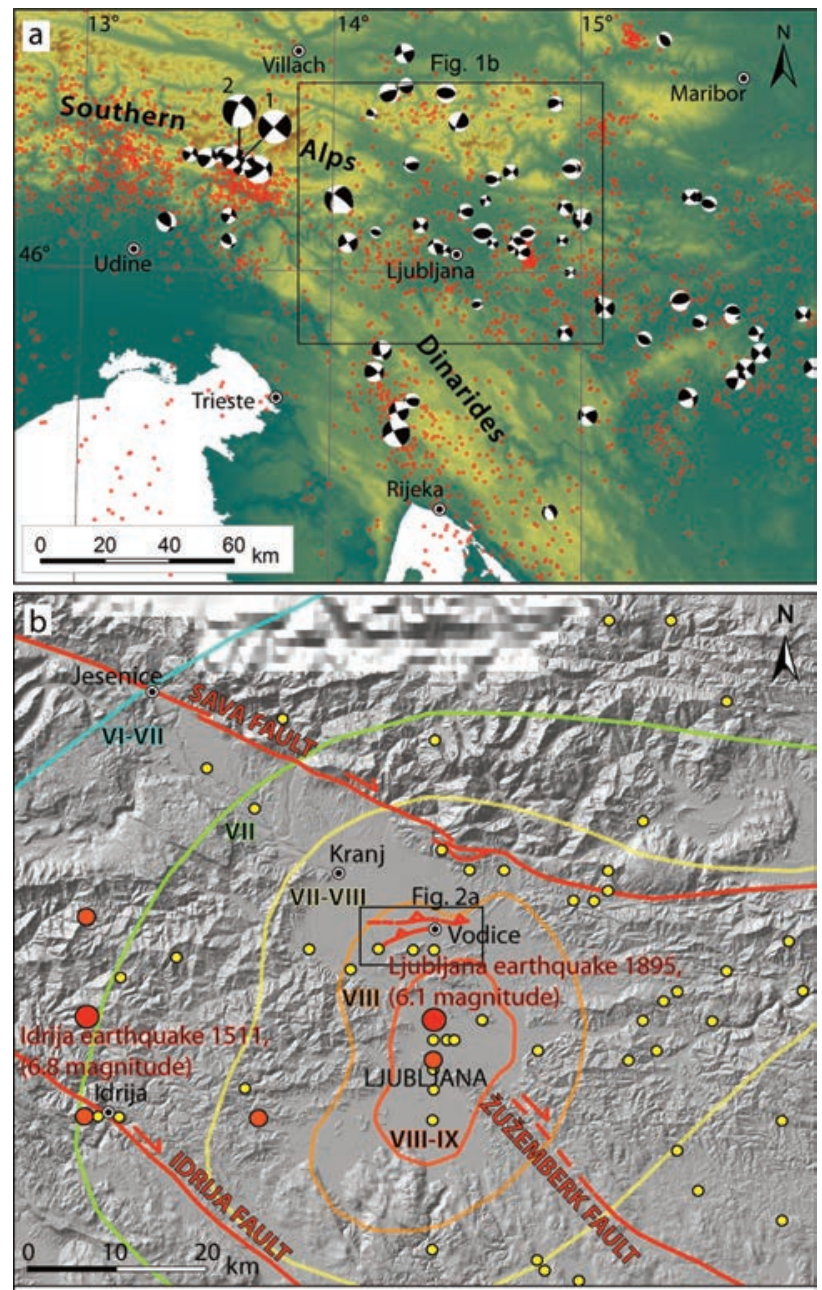

Figure 1. (a) Instrumental seismicity of the SE Alps and NW part of the Dinarides (ANSS catalogue, 1976-2012) and earthquake focal mechanisms [Bajc et al. 2001, Zupančič et al. 2001, Kastelic et al. 2006, 2008, Ložar Stopar and Živčič 2007, 2008, 2011, 2012, Čarman et al. 2010]. 1 - focal mechnism of the 1998 Ms 5.7 [Bajc et al. 2001], and 2 - focal mechanism of the $2004 \mathrm{Mw} 5.2$ earthquake [Kastelic et al. 2006]. Square indicates the location of Figure 1b. Topography is SRTM $90 \mathrm{~m}$, available from the Global Land Cover Facility (http://glcf.umd.edu/data/). (b) Main active faults of the Ljubljana Basin [modified after Buser 2009]. Historical earthquake epicentres with magnitude above 3.9 are from Živčič [2009]. Earthquake magnitudes are obtained from macroseismic data. Locations of historical earthquake epicentres are not well constrained. Isoseismal contours of the 1895 Ljubljana earthquake according to Lapajne [1989]. Shaded relief obtained from processing of DEM $5 \mathrm{~m}$ (Public Information of Slovenia, the Surveying and Mapping Authority of the Republic of Slovenia, DEM 5, 2006). Square indicates the location of Figure 2a.

approx. N-S direction. E-W-striking thrust faults in NE Italy and NW-SE-striking dextral faults across Slovenia, such as the Idrija fault, are most probably seismically active and reflect the present tectonic regime of that re- gion (Figures 1a, 1b) [Ribarič 1982, Poljak et al. 2000, Benedetti et al. 2000, Galadini et al. 2005, Kastelic et al. 2008, Burrato et al. 2008, Bavec et al. 2012, Basili et al. 2013]. This is also supported by the slip-vectors derived from earthquake focal mechanisms evidencing dextral slip on NW-SE fault-planes and thrust movements on E-W fault-planes [Bajc et al. 2001, Zupančič et al. 2001, Kastelic et al. 2006, 2008, Ložar Stopar and Živčić 2007, 2008, 2011, 2012, Čarman et al. 2010]. Only few events were attributed to a specific fault, among which the $1998 \mathrm{M}_{\mathrm{s}} 5.7$ [Bajc et al. 2001], and $2004 \mathrm{M}_{\mathrm{w}} 5.2$ earthquakes [Kastelic et al. 2006] that both occurred on the NW-SE right-lateral strike-slip Ravne fault (Figure 1a, focal mechanism solutions 1 for 1998 and 2 for 2004 earthquake). The strongest recorded historical earthquake in our study area was the Idrija 1511 earthquake with an estimated $\mathrm{M}_{\mathrm{m}} 6.8$ [Ribarič 1982] (Figure 1b). Its exact source and mechanism remain debated, but it most probably occurred along the NW-SE striking Idrija fault in western Slovenia [Fitzko et al. 2005, Camassi et al. 2011].

\section{Geomorphic and structural observations}

Surface expression of the Vodice fault was investigated using topographical maps at scales $1: 5,000$ and $1: 10,000$, the $5 \mathrm{~m}$ resolution digital elevation model (DEM $5 \mathrm{~m}$ ), aerial imagery, and $2.5 \mathrm{~m}$ resolution SPOT satellite images in stereo pairs. We performed geomorphological mapping of the alluvial surfaces in the area of the Vodice fault and analysed the characteristics of the drainage network. A series of topographic profiles parallel to and across the scarps was extracted from DEM $5 \mathrm{~m}$. Additional field observations were carried out to investigate deformations of alluvial surfaces.In the Vodice area, the general southward dip of the alluvial surface of the Ljubljana Quaternary basin is perturbed by linear features oriented in ENE-WSW direction, which are perpendicular to the general trend of fluvial terrace risers in the area, specifically those bordering the modern N-S flowing Sava River (Figure 2). Two nearly parallel scarps are visible, with the southern one being more prominent and here referred to as the southern Vodice (SV) scarp. Eastward, the northern Vodice (NV) scarp joins with the southern one. The height of the SV scarp varies from 25 to $5 \mathrm{~m}$, whereas the NV scarp varies in height from 18 to $3 \mathrm{~m}$. Both scarps are the highest in the central part with heights decreasing towards their eastern and western tips (Figure 3).

At the top of both scarps, the alluvial surface that was originally sloping southwards is today sub-horizontal or even dipping gently to the north. The top of alluvial surface is strongly incised by recent rivers and creeks. Several dry valleys and perched valleys are ob- 


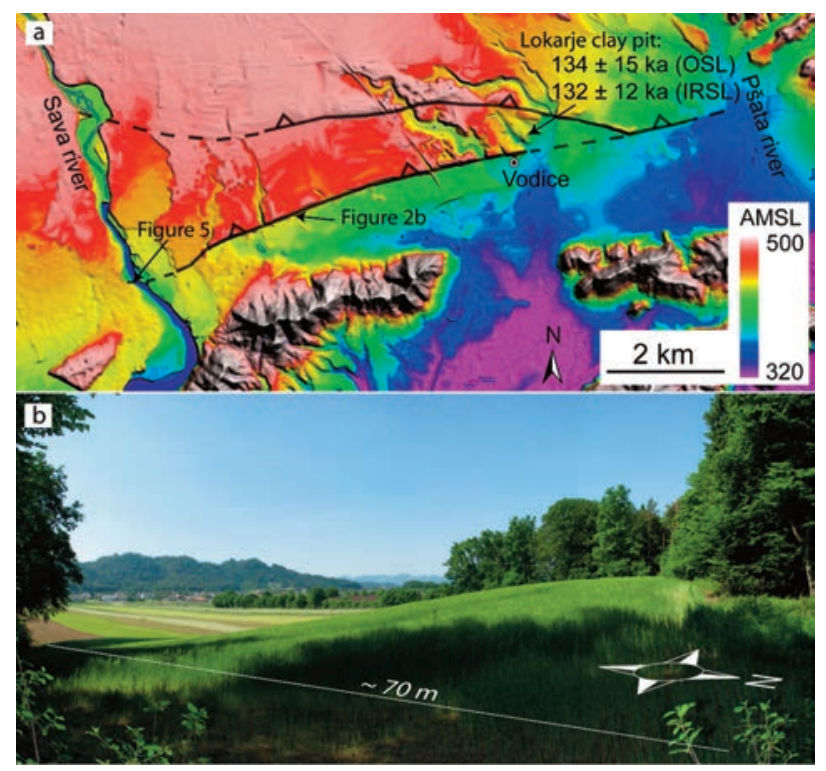

Figure 2. (a) Surface expression of the Vodice fault as seen on the DEM $5 \mathrm{~m}$ (Public Information of Slovenia, the Surveying and Mapping Authority of the Republic of Slovenia, DEM 5, 2006). Locations of Figure $2 \mathrm{~b}$ and Figure 5 are indicated as well as the location of the dating sampling site. (b) Field picture of the southern Vodice scarp (view from the top of the scarp towards southwest). See Figure $2 \mathrm{a}$ for location of the picture.

served near the scarps (Figure 3).

Folding of Quaternary sediments in the Lokarje clay pit, located in between the two SV and NV scarps, $400 \mathrm{~m}$ north of the town of Vodice, was reported by Drobne et al. [1960] and Šifrer [1961] (see Figure 4). They describe an asymmetric anticline with the southern limb dipping $40^{\circ}$ towards SSE and the northern limb dipping around $10^{\circ}$ towards NNW. The ENEWSW oriented anticline axis is parallel to the strike of the SV scarp.

At the western tip of the SV scarp, where it crosses the Sava River, we observed a fault cutting through Quaternary conglomerates (Figure 5). The fault plane dips $35^{\circ}$ to the north. Drag folds in conglomerate layers indicate reverse offset along this fault plane.

Our geomorphic and structural observations suggest that the SV scarp is the surface expression of an emergent fault. The position, vergence, and orientation of the Lokarje anticline are consistent with thrust/reverse faulting along the $S V$ fault scarp. Since the distance between the NV and the SV scarps is less than $2 \mathrm{~km}$ and because both scarps merge east of Vodice, we interpret the NV scarp as also the geomorphic expression of the same thrust fault that splays in two branches at the surface. We constrain the near-surface dip of the fault plane to about $35^{\circ} \mathrm{N}$, consistent with our observations along the Sava bank and with the geometry of the anticline in Lokarje. Documented deformations of Quaternary sediments and of alluvial surfaces clearly demonstrate that the Vodice fault has been active since at least the deposition of Quaternary conglomerates.
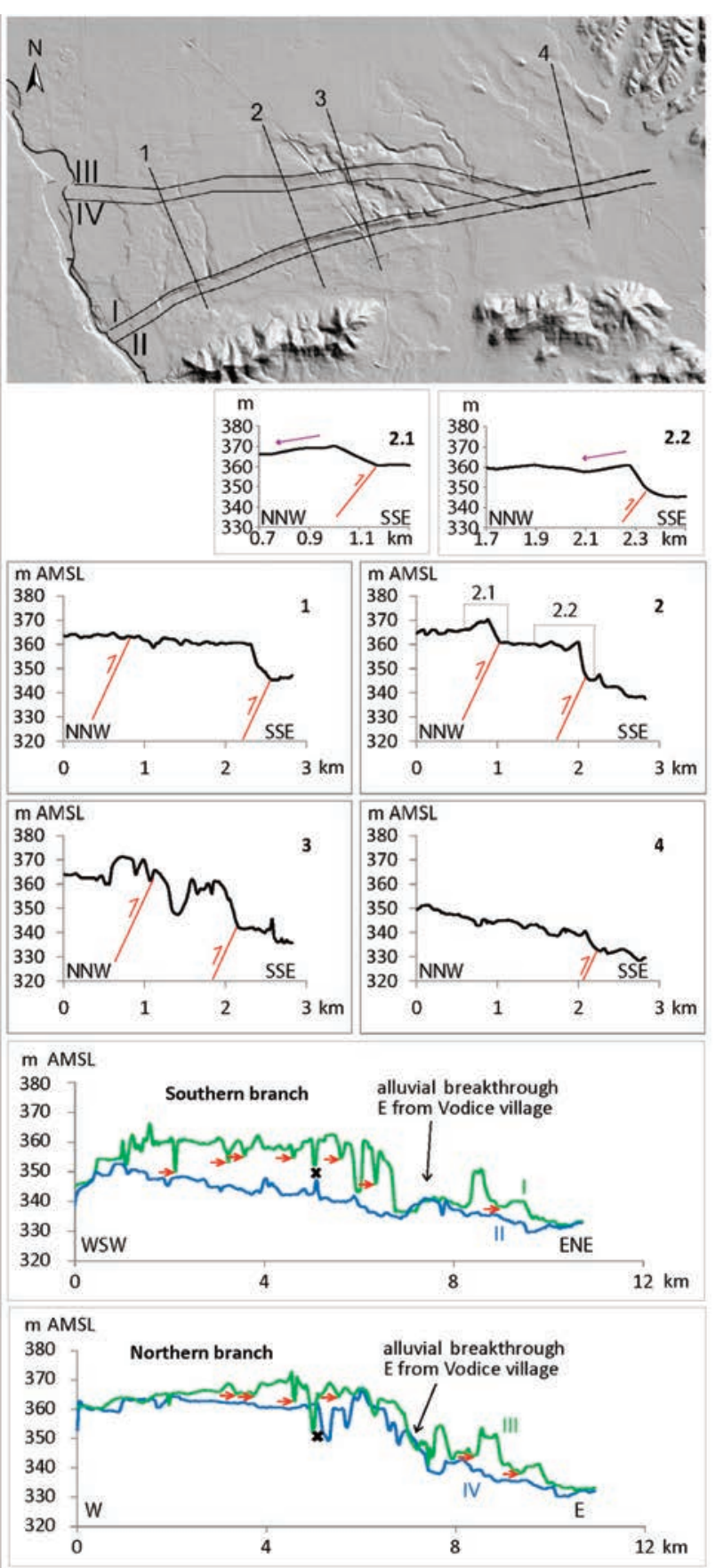

Figure 3. Series of topographic profiles extracted from DEM $5 \mathrm{~m}$ (Public Information of Slovenia, the Surveying and Mapping Authority of the Republic of Slovenia, DEM 5, 2006) across (profiles 14, 2.1 and 2.2), and parallel to (profiles I-IV) the Vodice scarps. Profiles 2.1 and 2.2 show a close-up on both scarps, where northward sloping is indicated with purple arrows on top of the scarps. Locations of profiles 2.1 and 2.2 are indicated in the profile 2. Profiles I and III present the scarps crest, and profiles II and IV present the scarps base. Red arrows in the profiles I and III indicate the positions of perched valleys, and black crosses indicate anthropogenic excavations due to highway construction.

\section{Dating}

In order to estimate the age of the offset surface north of the SV fault scarp, one sample was taken at $3 \mathrm{~m}$ depth in the fine-grained sediments from $5 \mathrm{~m}$ deep excavation. The sampling site is located in the immediate vicinity of a Lokarje clay pit, north of the SV fault scarp, 


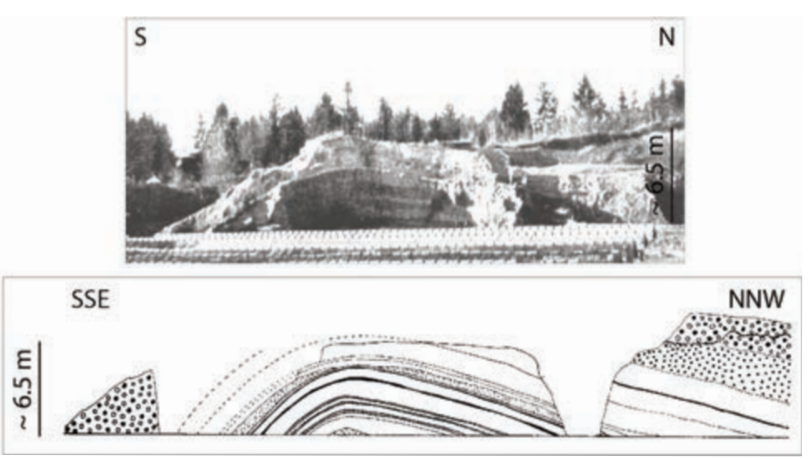

Figure 4. Picture and profile of an asymmetric anticline in Quaternary sediments in former Lokarje clay pit [Šifrer 1961]. See Figure 2 for location. The orientations of picture and the profile are inferred from the clay pit map in Šercelj [1961]. An approximate vertical scale is inferred from the description of the thicknesses of sediment layers in the profile.
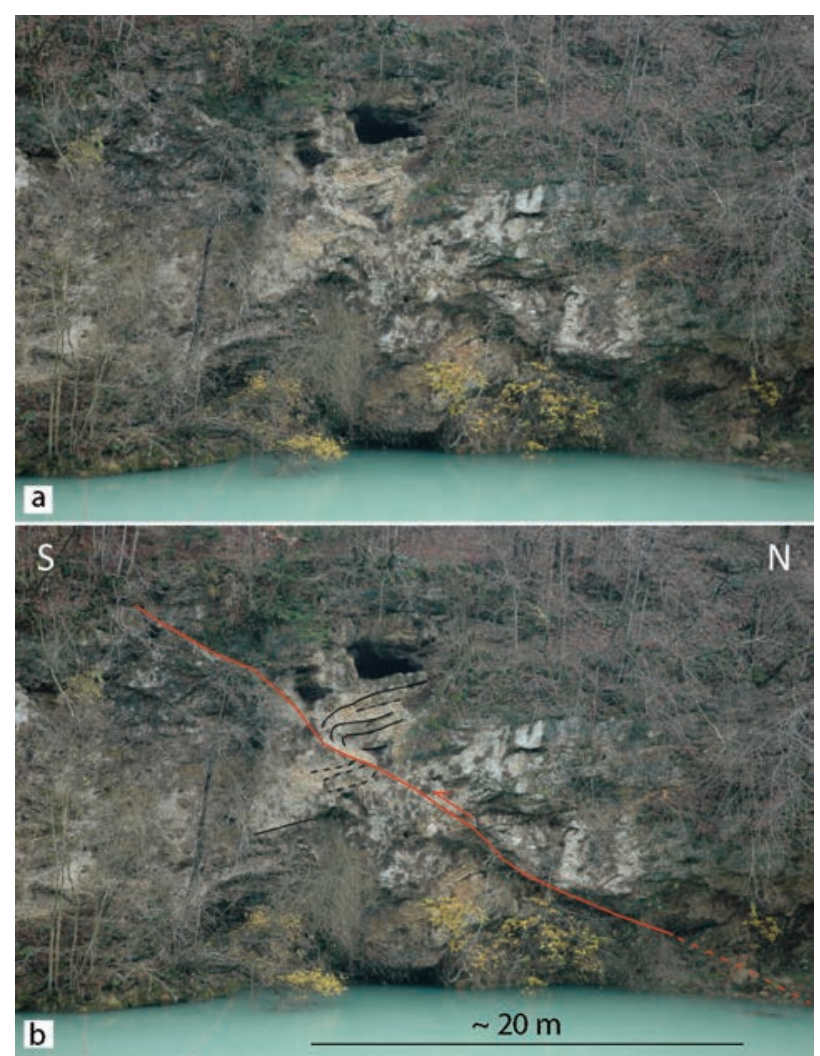

Figure 5. The fault plane of the southern Vodice fault exposed on the Sava River bank. (a) Picture of exposure. (b) Fault plane is indicated with red line and fault drag folds are indicated with black lines. The fault plane dips $35^{\circ}$ towards N. See Figure 2a for location.

at the W bank of alluvial breakthrough $\mathrm{E}$ of Vodice (see Figure 2 for location). Layers of clay, sand and conglomerate dipping around $10^{\circ}$ towards NNW are most probably part of the northern limb of the anticline described in the former clay pit. Layers of clays were deposited in lacustrine environment, intermediate conglomerate layers were deposited by fluvial processes.

Dating was carried out using both Optically Stimulated Luminescence (OSL) of quartz and Infrared Stimulated Luminescence (IRSL) of K-feldspar. Standard chemical pretreatments $\left(\mathrm{HCl}, \mathrm{H}_{2} \mathrm{O}_{2}\right.$, Na-oxalate) were applied to sand-sized grains $(100-150 \mu \mathrm{m})$ and heavy liquid separation was used to isolate the quartz and $\mathrm{K}$ feldspar fraction. Quartz was additionally etched in $40 \%$ $\mathrm{HF}$ for $60 \mathrm{~min}$. Determination of the equivalent dose was carried out by the single-aliquot regenerative dose (SAR) protocol (quartz: preheat $230^{\circ} \mathrm{C}$ for $10 \mathrm{~s}$, Hoya U340 detection filter; feldspar: preheat $290^{\circ} \mathrm{C}$ for $10 \mathrm{~s}$, L.O.T. Oriel $410 \mathrm{~nm}$ interference filter; $2 \mathrm{~mm}$ aliquots with ca. 100 grains). The Central Age Model was applied to calculate the mean of repeated measurements. Concentration of dose rate relevant elements was determined using high-resolution low-level gamma spectrometry. All relevant data is summarised in Table 1.

Those samples yielded an OSL age of $134 \pm 15 \mathrm{ka}$ and an IRSL age of $132 \pm 12$ ka for the upper alluvial surface. The ages are very consistent using two different dating approaches. The sediments were deposited by fluvial and lacustrine processes and then consecutively uplifted due to repeated fault movements. Because fluvial terraces E-W oriented are found nowhere else along the Sava River and because the river was in its most aggradational part, the preservation of those alluvial surfaces is probably of tectonic origin. Thus, their emplacement should slightly predate their offset. Since the OSL and IRSL methods allow determining the age of emplacement, those ages yield a maximum value for the offset. Moreover, since those samples were taken several meters from the surface, to further constrain the uplift rate, we are currently in the process of determining the surface exposure ages of the deformed surfaces using cosmogenic nuclides.

\section{Slip rate and seismogenic potential}

The presence of the presumably seismogenic Vodice thrust fault in the Ljubljana Basin, located only $15 \mathrm{~km}$ north of the capital of Slovenia, constitutes a significant seismic hazard for the population and a threat for both human lives and the economy of the country. To better assess this seismic hazard, we evaluated the fault slip rate and estimated its possible seismogenic potential.

We estimate the maximum cumulative displacement (D) of the fault by assuming it matches the height of the scarp (h) (taken from topographical maps at $1: 5,000$ scale) and the average fault $\operatorname{dip}(\alpha)$ as observed in the field:

$$
\mathrm{D}=\mathrm{h} / \sin (\alpha)
$$

The $h$ on the southern fault segment is $15.5 \pm 5 \mathrm{~m}$ and the observed dip, $\alpha$, is $35^{\circ} \mathrm{N}$. Thus the yielded $\mathrm{D}$ is $27.0 \pm 8.7 \mathrm{~m}$. Note that this $\mathrm{D}$ is probably overesti- 


\begin{tabular}{|c|c|c|c|c|c|c|c|c|c|c|}
\hline Sample & $\mathrm{n}$ & $\begin{array}{l}\mathbf{K} \\
(\%)\end{array}$ & $\begin{array}{c}\text { Th } \\
(\mathrm{ppm})\end{array}$ & $\begin{array}{c}\mathbf{U} \\
(\mathrm{ppm})\end{array}$ & $\begin{array}{c}\text { D-Q } \\
\left(\mathrm{Gy} \mathrm{ka}^{-1)}\right.\end{array}$ & $\begin{array}{c}\text { D-F } \\
\left(\mathrm{Gy} \mathrm{ka}^{-1)}\right.\end{array}$ & $\begin{array}{c}\text { ED-Q } \\
\text { (Gy) }\end{array}$ & $\begin{array}{l}\text { ED-F } \\
\text { (Gy) }\end{array}$ & $\begin{array}{c}\text { Age-Q } \\
\text { (ka) }\end{array}$ & $\begin{array}{l}\text { Age-F } \\
\text { (ka) }\end{array}$ \\
\hline LOK1 & $32 / 6$ & $0.52 \pm 0.01$ & $1.45 \pm 0.05$ & $2.90 \pm 0.13$ & $1.26 \pm 0.01$ & $1.74 \pm 0.01$ & $174.7 \pm 13.5$ & $237.6 \pm 13.1$ & $134 \pm 15$ & $132 \pm 12$ \\
\hline
\end{tabular}

Table 1. Summary data of OSL and IRSL dating giving the number of replicate measurements (n), the concentration of dose rate relevant elements $(K, T h, U)$, dose rate (D), equivalent dose (ED), and resulting ages for both quartz (Q) and feldspar (F).

mated since we have use simple trigonometric relations and a dip for the fault that might be higher at depth. On the other hand, considering scarp diffusional processes [e.g. Avouac and Peltzer 1993], the offsets might have been higher previously, however to remain conservative we assume this is a maximum value for the $D$.

Using OSL and IRSL ages of sediments (A) in Lokarje clay pit as the maximum ages of deformed surface we can estimate the preliminary Late Quaternary slip rate (SR) of the fault:

$$
\mathrm{SR}=\mathrm{D} / \mathrm{A} .
$$

This would yield a first estimate for the Vodice fault SR of 0.1 to $0.3 \mathrm{~mm} \mathrm{a}^{-1}$ over the last $133 \mathrm{ka}$.

The average magnitude (AM) expected on that fault was estimated as follows, using the empirical scaling relationships [Wells and Coppersmith, 1994], with the surface rupture length (SRL in $\mathrm{km}$ ) assumed at this stage to be equal to the length of the SV fault scarp, i.e. $10 \mathrm{~km}$ :

$$
\mathrm{AM}=\mathrm{a}+\mathrm{b}^{\star} \log (\mathrm{SRL})
$$

where $a$ and $b$ are coefficients calculated for the reverse faults (Table 2). Average displacement (AD) per event was calculated using the empirical relationships [Wells and Coppersmith, 1994] as follows:

$$
\log (\mathrm{AD})=\mathrm{a}+\mathrm{b}^{\star} \log (\mathrm{SRL})
$$

taken the coefficients $a$ and $b$ for reverse faults as given in Table 3. Furthermore, a possible recurrence time of large earthquakes (RT) was calculated using our estimated $\mathrm{SR}$ and an $\mathrm{AD}$ as follows:

$$
\mathrm{RT}=\mathrm{AD} / \mathrm{SR} .
$$

According to these empirically derived equations [Wells and Coppersmith 1994], with a SRL of $10 \mathrm{~km}$, the Vodice fault could trigger an earthquake of M 5.9 to 6.5 with a coseismic AD of 0.1 to $0.9 \mathrm{~m}$. Assuming a constant SR, we estimate a RT from 300 to 9,000 yrs. Note that the longer the RT interval is, the stronger the associated expected earthquake could be. But even if assuming a coseismic $\mathrm{AD}$ of $0.1 \mathrm{~m}$ and the shortest RT interval, the expected earthquake magnitude could theoretically still reach 6.1 .

\section{Discussion and conclusions}

Preliminary results of our investigation confirm that the two scarps near Vodice are the surface expression of an emergent active thrust fault, striking ENE-WSW and dipping about $35^{\circ}$ towards N. Assuming that the OSL and IRSL ages yielded from the deposits of the upper deformed surface represent the maximum age for this surface, we estimate that this surface has been offset for

\begin{tabular}{llll}
\hline Equation & Slip type & Coefficients & Standard deviation
\end{tabular}

\begin{tabular}{lllll} 
& & & & \\
& & $a$ & $b$ & 0.28 \\
\hline$M=a+b \star \log (S R L)$ & reverse & 5.00 & 1.22 & 0.22 \\
\hline
\end{tabular}

Table 2. Regressions of surface rupture length (SRL in km) and moment magnitude (M) [Wells and Coppersmith 1994].

\begin{tabular}{llll}
\hline Equation & Slip type & Coefficients & Standard deviation
\end{tabular}

a $\quad b$

\begin{tabular}{lllll}
\hline $\mathrm{M}=\mathrm{a}+\mathrm{b}^{\star} \log (\mathrm{SRL})$ & reverse & -0.60 & 0.31 & 0.28
\end{tabular}

Table 3. Regressions of surface rupture length (SRL in km) and average displacement (AD in m) [Wells and Coppersmith 1994]. 
about $15 \mathrm{~m}$ over the last $133 \mathrm{ka}$. At this stage, disregarding surface denudation that might be higher in the uplifted hangingwall compartment, and possible syntectonic aggradation in the footwall compartment of the SV fault, the height of the scarp may present the minimum uplift value. Assuming that all the surface offsets of $15.5 \pm 5 \mathrm{~m}$ determined from the topographic maps is due to an uplift along a thrust fault and a fault dip of $35^{\circ} \mathrm{N}$, the cumulative displacement of $27.0 \pm 8.7 \mathrm{~m}$ is a maximum value. From maximum age of the surface, minimum uplift and maximum displacement the estimated Vodice slip rate of 0.1 to $0.3 \mathrm{~mm} \mathrm{a}^{-1}$ over the last $133 \mathrm{ka}$ probably presents the minimum value.

This estimated slip rate is within the range of similar values documented in the southeastern part of the Alpine orogenic system, e.g. the Broni-Stradella thrust fault in northwestern Apennines with an estimated uplift-rate of $0.3 \mathrm{~mm} \mathrm{a}^{-1}$ since Late Pleistocene [Benedetti et al. 2003] and thrusts in the eastern Southern Alps, e.g. Thiene-Udine thrust system in NE Italy with estimated vertical SR of 0.1 to $1 \mathrm{~mm} \mathrm{a}^{-1}$ [Castaldini and Panizza 1999, Benedetti et al. 2000, Galadini et al. 2005, Burrato et al. 2008]. Moreover, estimated slip rates of the right-lateral strike-slip faults in the vicinity of the investigated area are also within that range, Idrija and Ravne faults at 0.03 to $2 \mathrm{~mm} \mathrm{a}^{-1}$ [Burrato et al. 2008, Kastelic and Carafa 2012] and the Sava fault at 0.5 to $1.5 \mathrm{~mm} \mathrm{a}^{-1}$ [Vrabec et al. 2006].

We estimate that the Vodice fault could possibly trigger earthquakes with magnitudes from 5.9 to 6.5. The Vodice fault should therefore be monitored considering its location in the densely populated area and its proximity to Slovenia's capital Ljubljana. The surface expression of the fault, sharp and with a strong slope, suggests abrupt displacements associated with seismic events [e.g. Benedetti et al. 2003, McCalpin 2009]. Our preliminary theoretical estimates suggest that possible return time interval for destructive M 5.9 to 6.5 earthquakes would range from 300 to 9,000 yrs. The only known historical destructive seismic event in the area is the 1895 Ljubljana $M_{m} 6.1$ earthquake [Ribarič 1982]. The macroseismic intensity dataset [Cecić 1998] of this earthquake shows that the maximum intensities of VIII - IX EMS-98 were recorded south of the fault, between Vodice and Ljubljana. Since the Vodice fault is a reverse fault, maximum intensities would be expected in the hangingwall of the fault, north of Vodice. Therefore, unless the maximum intensities distribution is biased by the population, the Vodice fault was probably not the source of the 1895 earthquake, but since the time interval between two strong seismic events on the fault may be longer than the span of historical record in the region (about 1000 years), paleoseismological investigations will be required to unravel its possible seismic history. In the future, we will investigate the fault using geophysical survey in order to better understand the geometry of the fault at depth, and further detailed analysis of the surface deformations and their chronology will be done to better constrain the fault displacement and its slip rate.

Acknowledgements. This work was funded by the Slovenian Research Agency, through the project L1-2383 Seismotectonic model of the Ljubljana Basin (cofounded by the Slovenian Environment Agency), the project J6-4016 The adaptation patterns of human activities to the environmental changes after Last Glacial Maximum in Slovenia, the programme P1 - 0011 Regional geology and the Young Researcher Grant (contract 1000-09-310068). We also acknowledge SPOT image and the ISIS program for the satellite images. We are grateful to A. Moulin, R. Finkel, I. Mrak, J. Atanackov, B. Milanič and J. Horvat for help in the field. We thank to Slovenian Academy of Sciences and Arts, the publisher of monograph where the photo and profile of the Lokarje anticline were taken from (Šifrer, 1961), for their permission to publish this material. We are grateful to Vanja Kastelic, Bruno Tomljenović and the Associate Editor (Christoph Grützner) for their reviews and comments that improved the manuscript.

\section{References}

Avouac, J. and G. Peltzer (1993). Active tectonics in southern Xinjiang, China: Analysis of terrace riser and normal fault scarp degradation along the Hotan-Qira fault system. J. Geophys. R., 98, B12, 21773-21807.

Bajc, J., A. Aoudia, A. Saraò and P. Suhadolc (2001). The 1998 Bovec-Krn mountain (Slovenia) earthquake. Geophys. Res. Lett., 29, 9, 1839-1842.

Basili, R., V. Kastelic, M. B. Demircioglu, D. Garcia Moreno, E. S. Nemser, P. Petricca, S. P. Sboras, G. M. Besana-Ostman, J. Cabral, T. Camelbeeck, R. Caputo, L. Danciu, H. Domac, J. Fonseca, J. García-Mayordomo, D. Giardini, B. Glavatovic, L. Gulen, Y. Ince, S. Pavlides, K. Sesetyan, G. Tarabusi, M. M. Tiberti, M. Utkucu, G. Valensise, K. Vanneste, S. Vilanova and J. Wössner (2013). The European Database of Seismogenic Faults (EDSF) compiled in the framework of the Project SHARE. http: / / diss.rm.ingv.it/shareedsf/, doi: 10.6092/INGV.IT-SHARE-EDSF.

Bavec, M., T. Ambrožič, J. Atanackov, I. Cecić, B. Celarc, A. Gosar, P. Jamšek, J. Jež, D. Kogoj, B. Koler, M. Kuhar, B. Milanič, M. Novak, P. Pavlovčič Prešeren, S. Savšek, O. Sterle, B. Stopar, M. Vrabec, M. Zajc and M. Živčić (2012). Some seismotectonic characteristics of the Ljubljana Basin, Slovenia, Geophys. Res. Abstr., 14, 1.

Benedetti, L., P. Tapponnier, G. C. P. King, B. Meyer and I. Manighetti (2000). Growth folding and active thrusting in the Montello region, Veneto, northern Italy. J. Geophys. R.-Solid Earth, 105, B1, 739-766.

Benedetti, L., P. Tapponnier, Y. Gaudemer, I. 
Manighetti and J. Van der Woerd (2003). Geomorphic evidence for an emergent active thrust along the edge of the Po Plain: The Broni-Stradella fault. J. Geophys. Res., 108, B5, 2238.

Burrato, P., M. E. Poli, P. Vannoli, A. Zanferrari, R. Basili and F. Galadini (2008). Sources of M(w) $5+$ earthquakes in northeastern Italy and western Slovenia: An updated view based on geological and seismological evidence. Tectonophysics, 453, 1-4, 157-176.

Buser, S. (2009). Geological map of Slovenia 1:250.000, Geological Survey of Slovenia, Ljubljana.

Camassi, R., C. H. Caracciolo, V. Castelli and D. Slejko (2011). The 1511 Eastern Alps earthquakes: a critical update and comparison of existing macroseismic datasets. J. Seismol., 15, 191-213.

Castaldini, D. and M. Panizza (1991). Inventario delle faglie attive tra i fiumi Po e Piave e il Lago di Como (Italia settentrionale). Il Quaternario, 4, 333-410.

Cecić, I. (1998). Investigation of earthquakes (14001899) in Slovenia, Internal report for the BEECD project, Seismological Survey, Ljubljana, 1-38.

Čarman, M., M. Živčić and M. Ložar Stopar (2010). Earthquakes in the Gorenja vas region in January and February 2009. Earthquakes in 2009, EARS, Ljubljana, 65-71.

Drobne, F., R. Pavlovec and A. Šercelj (1960). Some analyses and problems of Pleistocene sediments at Lokarji near Vodice. Kamniški zbornik, 6, 163-194.

Fitzko, F., P. Suhadolc, A. Aoudia and G. F. Panza (2005). Constrains on the location and mechanism of the 1511 Western-Slovenia earthquake from active tectonics and modelling of macroseismic data. Tectonophysics, 404, 77-90.

Galadini, F., M. E. Poli and A. Zanferrari (2005). Seismogenic sources potentially responsible for earthquakes with $M \geq 6$ in the eastern Southern Alps (Thiene-Udine sector, NE Italy). Geophys. J. Int., 161, 3, 739-762.

Gosar, A., J. Rošer, B. Šket Motnikar, P. Zupančič (2010). Microtremor study of site effects and soil-structure resonance in the city of Ljubljana (central Slovenia), Bull. Earthq. Eng., 8, 3, 571-592.

Jemec, M. and M. Komac (2011). Rainfall patterns for shallow landsliding in perialpine Slovenia. Nat. hazards, 13 p., doi: 10.1007/s11069-011-9882-9.

Kastelic, V., M. Živčić, J. Pahor and A. Gosar (2006). Seismotectonic characteristic of the 2004 earthquake in Krn mountains. Earthquakes in 2004, EARS, Ljubljana, 78-87.

Kastelic, V., M. Vrabec, D. Cunningham and A. Gosar (2008). Neo-Alpine structural evolution and presentday tectonic activity of the eastern Southern Alps:
The case of the Ravne fault, NW Slovenia. J. Struct. Geol., 30, 963-975.

Kastelic, V. and M. M. C. Carafa (2012). Fault slip rates for the active External Dinarides thrust-and-fold belt. Tectonics, 31, TC3019.

Komac, B. and M. Zorn (2011). Flood risk percepition 2010 flood case study. Ujma, 25, 157-162.

Komac, M. and M. Ribičič (2006). Landslide susceptibility map of Slovenia at scale 1:250.000. Geologija, 49 (2), 295-309.

Lapajne, J. (1989). Veliki potresi na Slovenskem - III.: potres v Ljubljani leta 1895. Ujma, 3, 55-61.

Ložar Stopar, M. and M. Živčić (2007). Fault plane solutions of some stronger earthquakes in Slovenia in 2005. Earthquakes in 2005, EARS, Ljubljana, 57-62.

Ložar Stopar, M. and M. Živčić (2008). Fault plane solutions of some stronger earthquakes in Slovenia in 2006 and 2007. Earthquakes in 2007, EARS, Ljubljana, 48-53.

Ložar Stopar, M. and M. Živčić (2011). Fault plane solutions of some stronger earthquakes in Slovenia in 2008 and 2009. Earthquakes in 2010, EARS, Ljubljana, 71-75.

Ložar Stopar, M. and M. Živčić (2012). Fault plane solutions of some stronger earthquakes in Slovenia in 2010 and 2011. Earthquakes in 2011, EARS, Ljubljana, 58-62.

McCalpin, J. P. (Editor) (2009). Paleoseismology, 2nd ed. (Intern. Geophys. Ser., 95), Academic Press, Elsevier, Burlington (MA), 1-613.

Poljak, M., M. Živčić and P. Zupančič (2000). The seismotectonic characteristics of Slovenia. Pure Appl. Geophys., 157, 37-55.

Poljak, M., A. Gosar and M. Živčić (2010). Active tectonics in Slovenia, in Geology of the Adriatic area: International Geological Congress on the Adriatic Area (ADRIA 2006), Urbino, 19-20 June 2006, University of Bologna, Department of Earth and Geological-Environmental Sciences, (GeoActa ; Spec. pub. 3), 15-24.

Ribarič, V. (1982). Seismicity of Slovenia, Catalogue of earthquakes (792 A.D.-1981). Seismological Survey of Slovenia, Ljubljana. 1-649.

Šifrer, M. (1961). The basin of Kamniška Bistrica during the Pleistocene period. Slovenian Academy of Sciences and Arts, Ljubljana, 1-211.

Verbič, T. (2006). Quaternary-active reverse faults between Ljubljana and Kranj, central Slovenia. Razprave IV. razreda SAZU, 47 (2), 101-142.

Vrabec, M. (2001). Structural analysis of the Sava Fault zone between Trstenik and Stahovica. PhD thesis, University of Ljubljana, Faculty of Natural Sciences and Engineering, Department of Geology, Ljubl- 
jana, 1-94.

Vrabec, M. and L. Fodor (2006). Late Cenozoic tectonics of Slovenia: structural styles at the Northeastern corner of the Adriatic microplate, in The Adria microplate: GPS geodesy, tectonics and hazards Nicholas Pinter (Editor), (NATO Science Series. IV, Earth and Environmental Sciences, 61) Springer, Dordrecht, 151-168.

Vrabec, M., P. Pavlovčič Prešeren and B. Stopar (2006). GPS study (1996-2002) of active deformation along the Periadriatic fault system in northeastern Slovenia: tectonic model. Geol. Carpath., 57 (1), 57-65.

Weber, J., M. Vrabec, P. Pavlovčič Prešeren, T. Dixon, Y. Jiang and B. Stopar (2010). GPS-derived motion of the Adriatic microplate from Istria Peninsula and Po Plain sites and geodynamic implications. Tectonophysics, 483 (3-4), 214-222.

Wells, D. L. and K. J. Coppersmith (1994). New Empirical Relationships among Magnitude, Rupture Length, Rupture Width, Rupture Area, and Surface Displacement. Bull. Seism. Soc. Am., 84 (4), 9741002.

Zupančič, P., I. Cecić, A. Gosar, L. Placer, M. Poljak and M. Živčić (2001). The earthquake of 12 April 1998 in the Krn Mountains (Upper Soča valley, Slovenia) and its seismotectonic characteristics. Geologija, 44, 1, 169-192.

Živčić, M. (2009). Catalogue of earthquakes in Slovenia. Internal documentation, ARSO - Slovenian Environment Agency, Ljubljana.

Žlebnik, L. (1971). Pleistocene Deposits of the Kranj, Sora and Ljubljana Fields. Geologija, 14, 5-51.

\footnotetext{
^Corresponding author:Petra Jamšek Rupnik,

Geological Survey of Slovenia, Ljubljana, Slovenia;

email: petra.jamsek@geo-zs.si.

(C) 2013 by the Istituto Nazionale di Geofisica e Vulcanologia. All rights reserved.
} 